\title{
Native Language and Immigrant Labour Market Outcomes: An Alternative Approach to Measuring the Returns for Language Skills
}

\author{
Dan-Olof Rooth $\cdot$ Jan Saarela
}

Published online: 19 December 2007

(C) Springer Science + Business Media B.V. 2007

\begin{abstract}
In contrast with the conventional approach of studying the interrelation between immigrants' language skills and their chances of succeeding in the host country labour market, this article explores the relevance of having and not having a mother tongue in common with the native population for otherwise similar immigrants. This is accomplished by using linked register data from two countries, which makes it possible to separate people according to their native language. We find that immigrants who have their mother tongue in common with natives have substantially higher employment and income levels than immigrants who originate from the same country, but whose native language is linguistically different from the dominant language of the host country. The results support the view that language is a fundamental part of immigrants' human capital and thus promotes their labour market outcomes.
\end{abstract}

Résumé Contrairement à l'approche traditionnelle à l'étude de l'interrelation entre les habiletés langagières des immigrants et leurs chances de réussir dans le marché du travail du pays qui les accueille, nous abordons la pertinence de partager ou de ne pas partager une langue maternelle avec les personnes nées dans le pays (la population native) en étudiant des immigrants qui sont semblables autrement. Nous nous appuyons sur les données de registres de deux pays, ce qui permet de distinguer les gens selon leur langue maternelle. Les résultats indiquent que le niveau d'emploi et de revenu des immigrants qui ont la même langue maternelle que la population

D.-O. Rooth

Baltic Business School, University of Kalmar, Kalmar, Sweden

D.-O. Rooth $(\square)$

Center for Business and Policy Studies (SNS), Stockholm, Sweden

e-mail: dan-olof.rooth@hik.se

J. Saarela

Åbo Akademi University, Vaasa, Finland

e-mail: jan.saarela@abo.fi 
native est grandement supérieur à celui des immigrants originaires du même pays mais dont la langue maternelle est très différente de la langue dominante du pays hôte. Ces conclusions appuient la théorie voulant que la langue constitue un élément fondamental du capital humain des immigrants et influence ainsi leur réussite au sein du marché du travail.

Keywords Language skills $\cdot$ Mother tongue $\cdot$ Immigrants $\cdot$ Employment $\cdot$ Income

Mots clés Habiletés langagières $\cdot$ Langue maternelle $\cdot$ Immigrants $\cdot$ Emploi $\cdot$ Revenu

\section{Introduction}

A person's language constitutes a fundamental part of his or her human capital and thus enhances economic outcomes (Chiswick and Miller 2003). Most of the literature on language has focused on measuring the effect of the acquisition of language skills on immigrants' assimilation in the recipient country (Beenstock et al. 2001; Chiswick and Miller 1995; Dustmann and Fabbri 2003). These studies find that immigrants with good ability to read, write, and speak the language of the host country generally have higher employment and income levels than those with poorer ability. This is also the case in Sweden (Duvander 2001; Rooth 2004).

This article adds to this literature, but we use a new and alternative strategy. Instead of directly measuring individual language skills, we compare two groups of immigrants who originate from the same country but differ with regard to their mother tongue. Persons in the one group have the same mother tongue as natives of the host country, whereas those in the other group have a linguistically different mother tongue. Thus we compare immigrants with perfect skills in the language of the host country with immigrants with imperfect skills.

This approach relates to the idea that a greater linguistic difference of the origin language from the destination language is believed to reduce the economic integration of immigrants (Beenstock et al. 2001). An individual's economic performance may consequently be interrelated with how distant his or her mother tongue is from the dominant language of the host country (Chiswick and Miller 2005).

Earlier empirical studies concerned with the returns to language skills used data on immigrants from various source countries. This means that results for the returns to language may be confounded by latent country-specific characteristics such as the educational system or the possibilities of taking part in political and economic life in the source country. We circumvent these problems as we study two immigrant groups who are similar but differ with regard to mother tongue.

Our approach also has some obvious advantages over the conventional way of measuring language skills. Self-reported measures of language skills could bias the estimated returns as respondents may overestimate or underestimate their true abilities (Dustman and van Soest 2001, 2002; Berman et al. 2003). Language tests have been suggested as alternatives (Charette and Meng 1994). However, because such tests are costly to perform, sample sizes involved are generally small, and if there is selective participation, language skills may still be measured erroneously. A similar caveat applies to data from surveys, specifically if unobserved characteristics 
(people's ability or motivation, for example) correlate with language skills and the observed outcomes.

In this study the measure consists of persons' unique mother tongue and thus contains no direct error from measurement. Neither need we be concerned with selective participation, as the data used are from population registers and include all persons who fulfill certain conditions. The use of mother tongue as a divider between having perfect and imperfect language skills rather implies that we have an estimator for the lower limit of the returns to language skills. This is because some of the individuals included in the group with "imperfect skills" are likely to have good or very good skills. Thus we have a good opportunity to test the hypothesis that linguistic distance affects labour market performance and to compare our estimates with those using the conventional method.

Because decisions about how much governments should spend on language training for immigrants should be based on correct estimates for the returns to language skills, these issues are highly relevant also from a policy perspective.

\section{Settings for Analysis and Theoretical Underpinnings}

To study the interrelation between native language and labour market outcomes, we focus on Finns who have moved to Sweden. This group of immigrants can be divided into those with Swedish as their mother tongue and those with Finnish as their mother tongue. The former originate from the Swedish-speaking population of Finland who live intermingled with the Finnish-speaking population of the country. In Finland the Swedish speakers amount to barely $6 \%$ of the population, or about 300,000 persons. The two language groups are guaranteed the same constitutional rights, and they are equal in most observable respects. The Finnish Speakers, however, have a native language that is Uralic (Finno-Ugrian) and differs greatly from the Swedish language, which is Indo-European (Scandinavian) and used also by the native population of Sweden.

Each citizen's unique mother tongue is recorded in the population register in Finland. By linking Finnish data to Swedish data with regard to information prior to emigration, we know if a person has Finnish or Swedish as her native language. This information is not accessible from registers in Sweden.

Immigrants from Finland constitute the largest group of foreign-born in Sweden. At the beginning of the twenty-first century they amounted to just under 200,000 persons or about a fifth of all foreign-born in the country. Studies that have analysed these immigrants' labour market outcomes without separating the two language groups find that their employment and income levels are substantially lower than those of native Swedes. This has specifically been the case for men since the economic recession in the 1990s (Ekberg and Rooth 2004; Saarela and Rooth 2006). Because the Swedish-speaking immigrants have their mother tongue in common with native Swedes, it would be natural to expect their outcomes on the Swedish labour market to be better than those of Finnish-speaking Finns. Analyses that do not separate the two groups are consequently likely to underestimate the true success of the Swedish-speaking immigrants or, alternatively, overestimate the performance of the Finnish-speaking immigrants. 
Although our strategy for identifying the effect of language is based only on a separation of two groups according to mother tongue, we are fairly sure that any variation in outcome between Swedish-speaking and Finnish-speaking immigrants is primarily a result of their ability to speak Swedish. This is because alternative explanations that could be suggested - discrimination, cultural behaviour, networks, or selective migration - appear to be of limited importance.

No empirical or anecdotal evidence suggests that labour market discrimination against one of the two groups would be greater than discrimination against the other. If anything, we believe that both groups are perceived as Finns by employers in Sweden, specifically when considering that phonetic notations differ somewhat between native Swedes and Swedish-speaking Finns.

Having a common language may reflect a higher degree of cultural similarity with native Swedes (Hedberg and Kepsu 2003), which might facilitate integration into Swedish society. However, because both groups of immigrants have been subject to a similar education system and have equal constitutional rights in the home country, it seems unlikely that cultural patterns would differ sufficiently to explain variation in economic outcomes in the recipient country. In the economic literature little is known about how such interrelations between culture and economic phenomena work (Guiso et al. 2006).

Immigrants' networks are often considered important for gaining employment, specifically on arrival (Chiswick and Miller 1996). At least from a quantitative point of view, this would be of advantage to Finnish-speakers, however, because they are about four times as many as the Swedish-speaking immigrants in Sweden, and the number of persons in managerial positions is also substantially higher in the Finnish-speaking group.

According to recent studies that have used the same data (Saarela and Finnäs 2006b; Rooth and Saarela 2007), there is no clear evidence in support of the view that variation in economic outcomes between the two groups would be an artifact of differences in selective migration. Swedish speakers have higher immigration rates and lower return migration rates (Finnäs 1986, 2003), so there is a level difference, but the selection on observable and unobservable characteristics appears to be fairly similar. It may also be pointed out that the estimate for Swedish language on economic outcomes will be correct for any given migrant cohort as long as changes in the skills composition over time are similar in both groups.

\section{Data}

Our data consist of individuals born between 1926 and 1985, who emigrated from Finland after 1970 and were living in Sweden at the end of 1990 and at the end of 2001, respectively. ${ }^{1}$ These data are from the Swedish Total Population Register (TPR), which is produced by Statistics Sweden.

\footnotetext{
${ }^{1}$ For the descriptive statistics in the next section we have used data that also include persons who immigrated before 1970. These data are not used in the subsequent regression analysis, however, as they do not differentiate between Finnish-speaking and Swedish-speaking Finns.
} 
We chose to focus on people who at the time of measurement were aged between 25 and 50 years, in other words persons born between 1940 and 1976. The lower age limit is motivated by our wish to exclude people who moved to Sweden to study. The purpose of the upper limit is to exclude people eligible for early retirement.

The two cross sections are linked at the individual level and include several socioeconomic and demographic variables. The outcomes we study are the probability of being employed and work income. The employment variable states whether the individual has been working for at least $1 \mathrm{~h}$ during the measurement week, which occurred in October for the 1990 data and in November for the 2001 data. The income variable states the total individual work income for the year in question, thus constituting the payment for the actual work hours. Because those who work for the same hourly pay but for different number of hours will have different annual incomes, it is possible that this variable correlates with persons' work hours and the existence of part-time work. However, income differences between the language groups proved to be relatively insensitive to whether the data are restricted to people with incomes above some given income level. When work incomes are analysed we therefore, for simplicity sake, concentrate on individuals with positive work income.

Persons included in the study have been registered as residents in Finland in one of the Finnish censuses at the end of the years 1970, 1975, 1980, 1985, 1990, 1995 or 2000. The data are thus limited to those Finns who migrated to Sweden after 1970. It is through the link to these Finnish registers that we identified the individuals' mother tongue.

We linked individual data between the Swedish and Finnish registers by making use of national registration numbers, thus identifying people by birth date and sex, as well as by municipality of residence and by the year the person last immigrated to Sweden. On the basis of this information $85.2 \%$ of the Finns in the Swedish register could be uniquely identified in the Finnish register. Dropout due to failed linkage should be regarded as random, because two or several persons with the same birth date, sex, municipality of residence and immigration year were not separable. The proportion of Swedish speakers in the group of Finns in Sweden (who immigrated after 1970) turns out to be just above $17 \%$ in the year 1990 and $22 \%$ in 2001. Earlier estimates based on migration flows (Finnäs 1986) and information from questionnaire data (Leiniö 1984) indicate that in the 1970s the Swedish speakers made up about a quarter of all Finns living in Sweden.

\section{Native Language, Employment and Income From Work}

Table 1 shows employment rates and mean income (including positive work income alone) among people aged between 25 and 50 years, men and women being analysed separately for each year of observation. The first row of each panel states the proportion of employed native individuals (with Swedish-born parents) for the years 1990 and 2001 respectively. The next row states correspondingly the proportion of employed individuals among immigrated Finns of the same ages. The third row is limited to those Finns who immigrated to Sweden after 1970. Rows four and five are based on our linked data, separating Finnish-speaking from Swedish-speaking Finns. 
Table 1 Employment rate (\%) and mean income (in 1,000 SEK) in people aged 25-50 years

\begin{tabular}{|c|c|c|c|c|}
\hline & \multicolumn{2}{|l|}{ Men } & \multicolumn{2}{|l|}{ Women } \\
\hline & 1990 & 2001 & 1990 & 2001 \\
\hline \multicolumn{5}{|l|}{ Employment rate } \\
\hline Native Swedes & 93.0 & 87.6 & 90.7 & 83.6 \\
\hline Finns & $83.0(55,666)$ & $74.4(32,484)$ & $86.0(67,298)$ & $78.1(40,065)$ \\
\hline Immigrated after 1970 & $76.2(22,916)$ & $69.6(18,184)$ & $83.6(27,111)$ & $77.0(24,937)$ \\
\hline Finnish speakers & $72.9(14,617)$ & $64.4(10,570)$ & $82.8(18,439)$ & $76.1(16,191)$ \\
\hline Swedish speakers & $87.0(3,164)$ & $84.9(3,180)$ & $88.8(3,735)$ & $83.6(4,387)$ \\
\hline \multicolumn{5}{|l|}{ Mean income } \\
\hline Native Swedes & 236 & 266 & 156 & 175 \\
\hline Finns & $206(51,445)$ & $243(26,403)$ & $157(62,966)$ & $183(34,232)$ \\
\hline Immigrated after 1970 & $190(20,444)$ & $239(14,102)$ & $152(25,192)$ & $186(21,147)$ \\
\hline Finnish speakers & $178(12,828)$ & $220(7,430)$ & $151(17,086)$ & $186(13,351)$ \\
\hline Swedish speakers & $235(2,990)$ & $298(2,758)$ & $163(3,575)$ & $201(3,895)$ \\
\hline
\end{tabular}

Numbers in parentheses refer to the number of persons. The description for mean income is for persons with positive income in 2001 rates. 1 SEK is equal to 0.14 US\$. Sources: the Swedish total population register and the Finnish longitudinal population census file.

At this aggregate level, Swedish speakers have considerably higher employment rates than Finnish speakers, and the language group difference is greater among men than among women. In employment rates the absolute difference was about 14 percentage units for men in 1990, and as much as 20 percentage units in 2001. For women the corresponding figures are six and eight percentage units respectively.

The mean work income is also to the advantage of the Swedish speakers, and the difference between the language groups is again greater among men than among women. The pattern for median income, which is not reported here, is fairly similar. For men the difference in means amounted to 58,000 SEK in 1990 and to as much as 78,000 SEK in 2001 ( 1 SEK is equal to 0.14 US\$). Finnish-speaking women earned on average 13,000 SEK more than Finnish-speaking women in 1990 and 15,000 SEK more in 2001. In relative numbers, this means that Swedish-speaking male immigrants have more than $30 \%$ more income, and Swedish-speaking female immigrants about $10 \%$ more income than their Finnish-speaking counterparts. It should also be observed that employment levels and mean incomes of Swedish speakers for men as well as women are very close to those of native Swedes.

Because the language group differential tends to increase between cross-section dates, there is reason to follow the same individuals over time. This panel approach helps to elucidate whether and how the situation changes at the individual level and enables us to account for outcome differentials that are due to changes in the composition of the study population. ${ }^{2}$

Table 2 shows the proportion of people employed in 2001 distributed on the basis of employment or nonemployment in 1990. The difference in employment rates between Swedish and Finnish speakers is great in the group consisting of people who were employed in 1990 and even greater in the group who were

\footnotetext{
${ }^{2}$ Almost $20 \%$ of those observed in 1990 cannot be observed in the 2001 data, which means that they either died or moved out of Sweden. Saarela and Finnäs (2006a) provide a more in-depth analysis of this issue.
} 
Table 2 Employment rate (\%) in 2001 according to employment status in 1990, and mean individual income change between 1990 and 2001 (in 1,000 SEK)

\begin{tabular}{|c|c|c|c|c|c|}
\hline & \multicolumn{3}{|c|}{ Employment rate 2001} & \multicolumn{2}{|c|}{ Income change } \\
\hline & & Men & Women & Men & Women \\
\hline \multirow[t]{2}{*}{ Native Swedes } & Employed 1990 & 88.4 & 86.7 & \multirow[t]{2}{*}{43} & \multirow[t]{2}{*}{34} \\
\hline & Not employed 1990 & 50.2 & 51.4 & & \\
\hline \multirow[t]{2}{*}{ Finns } & Employed 1990 & $76.9(41,208)$ & $78.7(54,287)$ & \multirow[t]{2}{*}{$20(36,169)$} & \multirow[t]{2}{*}{$26(48,225)$} \\
\hline & Not employed 1990 & $29.3(6,560)$ & $34.6(7,805)$ & & \\
\hline \multirow[t]{2}{*}{ Immigrated after 1970} & Employed 1990 & $73.7(14,175)$ & $81.1(20,264)$ & \multirow[t]{2}{*}{$26(12,331)$} & \multirow[t]{2}{*}{$38(18,709)$} \\
\hline & Not employed 1990 & $28.5(3,293)$ & $41.5(3,361)$ & & \\
\hline \multirow[t]{2}{*}{ Finnish speakers } & Employed 1990 & $71.2(8,263)$ & $81.0(13,408)$ & \multirow[t]{2}{*}{$19(6,833)$} & \multirow[t]{2}{*}{$37(12,235)$} \\
\hline & Not employed 1990 & $26.6(2,232)$ & $40.9(2,310)$ & & \\
\hline \multirow[t]{2}{*}{ Swedish speakers } & Employed 1990 & $85.6(2,290)$ & $87.6(2,991)$ & \multirow[t]{2}{*}{$52(2,055)$} & \multirow[t]{2}{*}{$48(2,837)$} \\
\hline & Not employed 1990 & 46.8 (237) & $60.7(331)$ & & \\
\hline
\end{tabular}

Numbers in parentheses refer to the number of persons. The description is for people born 1940-1965 who were living in Sweden both in 1990 and 2001. The description for income change refers to people with positive income both in 1990 and 2001. Income change is in 2001 rates. Sources: the Swedish total population register and the Finnish longitudinal population census file

nonemployed that year. This result obtains for both men and women. The table also gives the mean change in individual work income between the 2 years. Both Swedish-speaking men and women demonstrate upward income mobility that is higher than that of Finnish speakers, and even of native Swedes. In relative numbers, the percentage change in income for Swedish-speaking male immigrants is $10 \%$ higher, and for Swedish-speaking female immigrants 5\% higher than for their Finnish-speaking counterparts.

At this aggregate level, outcome differentials observed may be influenced by variation in the distribution of background variables between the two language groups. To what extent this is the case can be studied by estimating regressions where we account for distributional differences in standard socioeconomic and demographic variables.

The variables used in this respect are age, length of education, county of residence, and length of residence in Sweden. ${ }^{3}$ Age is categorized into 5-year intervals, educational length into 1-year intervals, country of residence into 24 spatial areas, and time spent in Sweden into 5-year intervals. For the income regressions we also use occupation, which consists of 10 broad categories (dummies for the types of occupations according to Statistics Sweden's classification SSYK96). This variable is applicable only for employed persons, because in the register used it is gathered only for those who were working during the measurement week. On this point the results should therefore be interpreted with some caution.

Each of the variables is measured for the respective year under study (in Sweden) and for income change at the latter point under observation. ${ }^{4}$ Applying other

\footnotetext{
${ }^{3}$ Because length of residence is based on the most recent year of immigration, it is an underestimate of time spent in Sweden for repeated migrants.

${ }^{4}$ Considering the age structure and the length of stay in Sweden, most people in the data evidently obtained their education in Finland.
} 
categorizations of the variables, or measuring them at other times (where applicable), turned out not to change the overall conclusions. For the results reported here there are no indications of multicollinearity.

As can be seen in Table 3, which provides a brief description of the distribution of background variables by language group and sex, there are obvious reasons for studying if they underlie the variation observed at the aggregate level. The Swedish speakers have on average more years of education, and relatively more of them reside in the Stockholm region, which can be expected to favour their relative outcomes. Differences in years of education correspond with the situation in Finland (Saarela and Finnäs 2003a). Variation in geographical distribution seems to be caused by linguistic concentration in the sense that newly arrived Finnish-speaking immigrants settle in areas where many Finnish speakers have found work earlier such as Volvo industries in the Gothenburg area. Swedish speakers, on the other hand, appear to be directed more toward the service-oriented and expanding capital area, where they can be expected to make relatively good use of their Swedishlanguage skills. As compared with Finnish speakers, a higher relative proportion of the Swedish speakers also tend to work in occupations that generate higher incomes. The occupational distribution is less similar across language groups among men than among women, which implies that income differences for men are likely to be more affected than those for women when occupation is taken into account. The mean Finnish speaker in the data is older and has spent more time in Sweden than the corresponding Swedish speaker. This variation, though, appears to be driven principally by a higher rate of recent immigration of Swedish speakers, not by language group differentials in selective return migration.

Table 3 Descriptive overview of the data (persons aged 25-50 years)

\begin{tabular}{|c|c|c|c|c|c|c|c|c|}
\hline & \multicolumn{4}{|l|}{ Men } & \multicolumn{4}{|l|}{ Women } \\
\hline & \multicolumn{2}{|l|}{1990} & \multicolumn{2}{|l|}{2001} & \multicolumn{2}{|l|}{1990} & \multicolumn{2}{|l|}{2001} \\
\hline & $\begin{array}{l}\text { Finnish } \\
\text { speakers }\end{array}$ & $\begin{array}{l}\text { Swedish } \\
\text { speakers }\end{array}$ & $\begin{array}{l}\text { Finnish } \\
\text { speakers }\end{array}$ & $\begin{array}{l}\text { Swedish } \\
\text { speakers }\end{array}$ & $\begin{array}{l}\text { Finnish } \\
\text { speakers }\end{array}$ & $\begin{array}{l}\text { Swedish } \\
\text { speakers }\end{array}$ & $\begin{array}{l}\text { Finnish } \\
\text { speakers }\end{array}$ & $\begin{array}{l}\text { Swedish } \\
\text { speakers }\end{array}$ \\
\hline Mean age & 36.7 & 36.6 & 35.7 & 35.8 & 40.6 & 38.7 & 40.9 & 38.4 \\
\hline $\begin{array}{l}\text { Mean years of } \\
\text { schooling }\end{array}$ & 10.1 & 11.3 & 10.8 & 12.3 & 11.1 & 11.8 & 11.9 & 12.9 \\
\hline $\begin{array}{l}\text { At most } 10 \text { years in } \\
\text { sweden }(\%)\end{array}$ & 38.0 & 56.3 & 23.4 & 36.2 & 31.9 & 37.9 & 18.8 & 34.5 \\
\hline $\begin{array}{l}\text { Living in county of } \\
\text { Stockholm }(\%)\end{array}$ & 44.4 & 58.9 & 42.2 & 57.5 & 50.6 & 58.9 & 48.2 & 56.3 \\
\hline \multicolumn{9}{|l|}{ Occupation (\%) } \\
\hline $\begin{array}{l}\text { Professionals, } \\
\text { technicians }\end{array}$ & 9.9 & 27.7 & 16.6 & 38.2 & 24.9 & 33.0 & 35.6 & 48.0 \\
\hline $\begin{array}{l}\text { Craft workers, plant } \\
\text { operators }\end{array}$ & 59.2 & 37.4 & 48.9 & 26.1 & 13.4 & 5.8 & 8.2 & 2.6 \\
\hline $\begin{array}{l}\text { Elementary } \\
\text { occupations }\end{array}$ & 5.6 & 2.7 & 7.0 & 3.3 & 15.9 & 6.4 & 10.7 & 4.3 \\
\hline Other & 25.3 & 32.2 & 27.5 & 32.4 & 45.8 & 54.8 & 45.5 & 45.1 \\
\hline
\end{tabular}

Occupational distribution is only for employed people (those who worked at least $1 \mathrm{~h}$ during the measurement week). Sources: the Swedish total population register and the Finnish longitudinal population census file.

를 Springer 
The results of the regressions are summarized in Tables 4 and 5. These show what happens with the outcome differential between Swedish and Finnish speakers when additional background variables are included in the estimates (complete tables with all estimates are available from the authors upon request). ${ }^{5}$

It appears clear that variation in educational distribution between the two language groups is the single most important variable for explaining the outcome differentials. The education variable reduces the difference in employment probability and in income by approximately a quarter, somewhat dependent on sex and observation year. For persons employed in the measurement week (numbers in parentheses), the income differential is further reduced when occupation also is taken into account.

For individuals who appear to be lacking in work experience in particular (persons who were unemployed in 1990), educational distribution plays a specifically important role. The same applies to the between-group differential in relative income mobility. When we further restrict the data to people with positive work income in both years who also were employed in the measurement week in 2001, the percentage difference in relative income change disappears, and when occupation is accounted for, the Finnish speakers even appear to have higher income mobility than Swedish speakers. This suggests that language skills and occupation are interrelated and thus underlie upward income mobility. These results are dependent on how income change is measured, however. In absolute numbers a small difference in favour of the Swedish speakers remains (not shown).

The widening of the language-group outcome differential between 1990 and 2001 is interpreted as reflecting increasing returns to language skills over time. This would lend additional support for the view that Swedish language really is the factor that underlies variation in outcomes between the two groups, because the Swedish economy has become more service-oriented and the need for Swedish-language skills are increasingly more in demand (cf. Rosholm et al. 2006).

To explore the role of language on employment and income levels further, we explicitly account for time spent in Sweden using an interaction effect between native language and duration of stay. As the Finnish speakers can be assumed to improve their Swedish-language skills with time spent in Sweden, differences in labour market outcomes as compared with the Swedish-speaking immigrants would be smaller for those having spent more time in Sweden than for those having spent less time in Sweden (as observed at the cross section level). ${ }^{6}$

The results, which are summarized in Table 6 by cross-section year and sex, support these expectations. For the most recent immigrant cohort, the advantage of the Swedish-speaking immigrants in terms of employment levels is substantially higher than for those who have spent many years in Sweden. In 1990 the difference

\footnotetext{
${ }^{5}$ In practice we have estimated regressions of the form $Y=\alpha+\beta \times$ Swedish speaker $+\delta \times$ Control variables, where $\beta$ alone is stated in Tables 4 and 5. Regressions for income and income change have been estimated by the ordinary least squares method, and the probability of being employed by nonlinear regression of the probit type, for which the marginal effect has been calculated.

${ }^{6}$ It should be noted that a similar result would arise in case over time there is a selection on Swedishlanguage skills in the Finnish-speaking population, so that the least skilled in this respect were those who return migrate.
} 
Table 4 Contribution of background variables on the language-group difference in employment and in income

\begin{tabular}{|c|c|c|c|c|}
\hline & \multicolumn{2}{|l|}{ Men } & \multicolumn{2}{|l|}{ Women } \\
\hline & 1990 & 2001 & 1990 & 2001 \\
\hline \multicolumn{5}{|l|}{ Difference in employment rate $(\times 100)$} \\
\hline No control for background variables & 14.1 & 20.5 & 6.0 & 7.5 \\
\hline \multicolumn{5}{|l|}{ Control for } \\
\hline Age + duration + county & 14.5 & 20.5 & 5.9 & 8.2 \\
\hline Age + duration + county + education & 12.2 & 16.6 & 4.4 & 6.0 \\
\hline \multicolumn{5}{|l|}{ Difference in log income $(\times 100)$} \\
\hline No control for background variables & $35.4(23.0)$ & $31.2(19.7)$ & $12.1(6.0)$ & $8.7(5.6)$ \\
\hline \multicolumn{5}{|l|}{ Control for } \\
\hline Age + duration + county & $37.9(24.5)$ & $31.7(19.1)$ & $11.0(5.2)$ & $12.8(6.7)$ \\
\hline Age + duration + county + education & $30.5(19.8)$ & $22.7(13.0)$ & $8.3(3.8)$ & $8.8(4.4)$ \\
\hline Age + duration + county + education + occupation & $(17.2)$ & $(8.7)$ & (3.1) & $(2.2)$ \\
\hline
\end{tabular}

Difference refers to difference between Swedish speakers and Finnish speakers. The description is for people aged 25-50 years, who were living in Sweden in 1990 and in 2001 respectively. The standardization uses the following variables: Age in 5-year intervals, Duration (time in Sweden in 5year intervals, County of residence, Educational length in one-year intervals, and occupation in 10 broad categories according to SSYK96. Numbers in parentheses are for people who were employed (worked at least $1 \mathrm{~h}$ during the measurement week). Occupation is applicable only for these employed persons. The language-group difference is statistically significant at the $1 \%$ level, except in the italics case. Adjusted Rsquares for regressions referred to in the last row are $(0.144),(0.208),(0.137)$ and $(0.157)$. Sources Authors' calculations based on the Swedish total population register and the Finnish longitudinal population census file

was 15 percentage units and in 2001 as much as 23 percentage units, which also indicates that language has become more important over time. For women the corresponding differences were eight and 11 percentage units respectively. These estimates are in line with results from the United Kingdom (Dustmann and Fabbri 2003), and twice the estimates of previous studies from Sweden (Rooth 2004; Rooth and Åslund 2006).

Also for income we can see that outcome differentials between the language groups are larger for more recent immigrant cohorts than for earlier ones, although the pattern is not altogether consistent. In 1990 the difference across language groups was $33 \%$ in the most recent male immigrant cohort, and in 2001 it was $23 \%$. Corresponding differentials among women were $11 \%$ and $12 \%$, respectively. For women our estimates correspond with those found elsewhere in the literature, but for men they are larger (Chiswick and Miller 1995). The effect of language on income levels does not consequently seem to have increased over time. It is possible, however, that this is because the competition for jobs has become so strong since 1990 that the importance of language ability is reflected in employment opportunities.

Restricting the data to people who were employed in the measurement week and controlling for occupation (numbers in parentheses) shows that the above-mentioned pattern remains strong, except for women in 2001 for whom language-group differentials became fairly small. Hence although we cannot rule out the possibility that Finnish speakers who remain in Sweden are selected on Swedish-language 
Table 5 Contribution of background variables on the language-group difference in employment rate in 2001 according to employment status in 1990, and in individual income change

\begin{tabular}{|c|c|c|}
\hline & Men & Women \\
\hline \multicolumn{3}{|l|}{ Difference in employment rate in $2001(\times 100)$} \\
\hline \multicolumn{3}{|l|}{ Employed in 1990} \\
\hline No control for background variables & 14.4 & 6.6 \\
\hline \multicolumn{3}{|l|}{ Control for } \\
\hline Age + duration + county & 14.3 & 6.3 \\
\hline Age + duration + county + education & 12.2 & 5.2 \\
\hline \multicolumn{3}{|l|}{ Employed in 1990} \\
\hline No control for background variables & 20.2 & 19.8 \\
\hline \multicolumn{3}{|l|}{ Control for } \\
\hline Age + duration + county & 17.6 & 17.9 \\
\hline Age + duration + county + Education & 11.4 & 12.1 \\
\hline \multicolumn{3}{|c|}{ Difference in change in log income from 1990 to $2001(\times 100)$} \\
\hline No control for background variables & $10.0(0.8)$ & $5.3(1.1)$ \\
\hline \multicolumn{3}{|l|}{ Control for } \\
\hline Age + duration + county & $6.7(-1.6)$ & $5.2(1.3)$ \\
\hline Age + duration + county + education & $2.2(-4.7)$ & $3.7(0.5)$ \\
\hline Age + duration + county + education + occupation & $(-6.2)$ & $(-0.6)$ \\
\hline
\end{tabular}

The description is for people aged 25-50 years in 1990 who were living in Sweden in both 1990 and 2001. The descripition for income change is for people with positive income in both 1990 and 2001. The language-group difference is statistically significant at the $1 \%$ level except for in the italics cases. Adjusted R-squares for regressions referred to in the last row are $(0,087)$ and $(0.147)$. See also the notes for Table 4.

skills, we believe that our results should be seen as clear support for the important role of native language on labour market outcomes.

\section{Discussion and Conclusions}

In this article, the issue of specific interest has been to analyse to what extent having perfect language skills, as measured by having and not having a mother tongue in common with the native population, affects immigrants' labour market performance. We compared two groups of immigrants who originate from Finland but differ in their native language. The Swedish-speaking immigrants have their mother tongue in common with the native population of Sweden, whereas the Finnish-speaking immigrants' first language is linguistically distant from the Swedish language.

Compared with conventional methods, the main advantages of our approach are that we have no errors in measurement or endogeneity of the traditional kind and that there is no selective participation. Our estimate should also be interpreted as providing a lower limit for the returns for perfect language skills, because some of the Finnish-speaking immigrants might also have perfect or good Swedish-language skills. However, little is known about the number of Finnish speakers who have learned Swedish to a level equivalent to that of native speakers.

Given this, it is noteworthy that our estimates in most instances are substantially higher than those found elsewhere in the literature. For example, in 2001 newly arrived Finnish men with "perfect" language skills had an employment probability 
Table 6 Language-group difference in employment and in income by year of immigration

\begin{tabular}{|c|c|c|c|c|}
\hline & \multicolumn{2}{|l|}{ Men } & \multicolumn{2}{|l|}{ Women } \\
\hline & 1990 & 2001 & 1990 & 2001 \\
\hline \multicolumn{5}{|c|}{ Difference in employment rate $(\times 100)$} \\
\hline \multicolumn{5}{|c|}{ Immigration year } \\
\hline $1971-1975$ & 6.3 & 9.9 & 2.1 & 3.7 \\
\hline $1976-1980$ & 10.0 & 12.2 & 3.1 & 3.8 \\
\hline $1981-1985$ & 15.6 & 16.3 & 6.3 & 5.0 \\
\hline $1986-1990$ & 15.3 & 12.0 & 7.8 & 5.4 \\
\hline $1991-1995$ & & 18.8 & & 8.8 \\
\hline $1996-2001$ & & 22.9 & & 10.9 \\
\hline \multicolumn{5}{|c|}{ Difference in log income $(\times 100)$} \\
\hline \multicolumn{5}{|c|}{ Immigration year } \\
\hline $1971-1975$ & $19.7(13.3)$ & $12.3(0.7)$ & $1.9(0.3)$ & $9.6(6.7)$ \\
\hline $1976-1980$ & $27.9(18.0)$ & $14.8(5.7)$ & $6.6(2.7)$ & $8.6(2.4)$ \\
\hline $1981-1985$ & $41.4(17.6)$ & $32.9(13.9)$ & $15.2(7.4)$ & $3.5(0.8)$ \\
\hline 1986-1990 & $33.4(17.4)$ & $25.9(10.9)$ & $11.3(2.3)$ & $3.5(-1.1)$ \\
\hline 1991-1995 & & $37.2(15.5)$ & & $16.7(5.4)$ \\
\hline 1996-2001 & & $23.0(7.9)$ & & $12.3(0.9)$ \\
\hline
\end{tabular}

Calculations are based on models that include interaction effects between language group and immigration year, together with the variables age, county of residence and educational length. Numbers in parentheses refer to people who were employed (worked at least $1 \mathrm{~h}$ during the measurement week). Occupation is also included in those estimates. The language-group difference is statistically significant at the $1 \%$ level, except for in the italic cases. See also the notes for Table 4.

that was 23 percentage points higher than those with "imperfect" language skills. The corresponding number for women was 11 percentage points. Income differences between the two groups were $23 \%$ for men and $12 \%$ for women. Hence the estimates for men are similar in magnitude to the heavily criticized instrumental-variables estimates of Chiswick and Miller (1995) and indicate that language skills are even more important for immigrants' success than earlier analyses have suggested.

Further, we believe that differences in outcomes between men and women are because Finnish-speaking women have better Swedish-language skills than Finnish-speaking men. Some data indicate that this might be the case. During 1995 and 1998 interviews were conducted with a total of 127 randomly sampled Finns in Sweden in the framework of the International Adult Literacy Survey (OECD 2000; Skolverket 2000). The aim was to study adult reading ability in Swedish. Persons interviewed were asked which language they had first learned as children. Approximately $28 \%$ of the Finns said that they had learned Swedish as their first language, which indicates that they were Swedish speakers. Using these data, we find a significant difference in reading ability between Swedish-speaking and Finnish-speaking men, but not between Swedish-speaking and Finnish-speaking women. This gender differential remains and is even higher when age at migration, length of residence in Sweden, and education are taken into account (Table 7).

To the extent that these data are representative, variation in Swedish-language skills between sexes may, therefore, explain our results. It is highly relevant, but of course difficult, to know what underlies such potential variation. It could be that 
Table 7 OLS estimates for between-group difference in Swedish language skills for Finns in Sweden $(\mathrm{n}=127)$

\begin{tabular}{llll}
\hline & Model 1 & Model 2 & Model 3 \\
\hline Finnish-speaking woman & - & - & - \\
Finnish-speaking man & $-0.347^{*}$ & $-0.411^{*}$ & $-0.325^{\mathrm{a}}$ \\
Swedish-speaking woman & 0.013 & 0.087 & 0.096 \\
Swedish-speaking man & -0.008 & 0.114 & 0.261 \\
Controls for & & & Yes \\
Age at migration & No & Yes & Yes \\
Time in Sweden & No & Yes & Yes \\
Education & No & No & 0.19 \\
Adjusted R-squared & 0.03 & 0.14 & \\
\hline
\end{tabular}

Data are from the IALS, for the years 1995 and 1998. Language skills are measured on a five-point scale, where 3 is regarded as having reading skills compatible with the average student in 9th grade.

${ }^{a}$ Refers to an estimate that is statistically significant at the $10 \%$ level

women have work tasks requiring a higher degree of communication in Swedish than do men. Still, we know of no previous study in Sweden or elsewhere that finds a marked difference between men and women of the same nationality and the same mother tongue as regards their knowledge of the language of the destination country.

During the past 50 years immigrants from Finland have constituted the single most important element for filling the demand for labour needed in Sweden (Saarela and Rooth 2006). There has been free mobility of labour between the countries ever since 1954 when a common Nordic labour market was established. This implies that no regulations have stipulated language or other skills as conditions for entry. This experience may teach other countries about the potential consequences of migrant flows that are not restricted by requirements for residence, work, or other permits.

In Finland knowledge of Swedish is generally poor among people who do not practice it in everyday life, even though it is a mandatory subject in the curriculum in compulsory education. However, studies from Finland also indicate that language skills are important for economic outcomes. Swedish speakers are generally believed to have better language skills than the Finnish speakers in the sense that relatively more of them speak both Swedish and Finnish fluently. This assumed variation in language skills is believed to explain their lower unemployment rates, as well as their higher wages in the Helsinki area (Saarela and Finnäs 2003b, 2004, 2006b).

In Sweden only a third of all immigrants who are entitled to publicly funded language training (Svenska för invandrare) finish the courses. Considering the main results of this study, which indicate that perfect skills in the dominant language of the recipient country highly promote immigrants' labour market outcomes, we are convinced that more public attention should be focused on increased language training and efforts to enhance individuals' interest in learning languages. Governments should publicize that good language skills greatly improve labour market outcomes, and individuals need to learn how their language skills improve during the integration process. A Web-based language test, for example, could be developed for immigrants to verify their language skills at various times. 
Acknowledgements Comments received from two anonymous referees, Peter Grant, Fjalar Finnäs, Per Skedinger, and seminar participants at SOFI (Stockholm university) have been very helpful. Financial support from the Swedish-Finnish Cultural Foundation (Saarela) and the Swedish Council for Working Life and Social Research (Rooth) is also gratefully acknowledged.

\section{References}

Beenstock, M., Chiswick, B. R., \& Repetto, G. L. (2001). The effect of linguistic distance and country of origin on immigrant language skills: Application to Israel. International Migration, 39, 33-60.

Berman, E., Lang, K., \& Siniver, E. (2003). Language-skill complementarity: Returns to immigrant language acquisition. Labour Economics, 10, 265-290.

Charette, M., \& Meng, R. (1994). Explaining language proficiency. Economics Letters, 44, 313-321.

Chiswick, B. R., \& Miller, P. W. (1995). The endogeneity between language and earnings: International analyses. Journal of Labor Economics, 13, 246-288.

Chiswick, B. R., \& Miller, P. W. (1996). Ethnic networks and language proficiency among immigrants. Journal of Population Economics, 9, 19-35.

Chiswick, B. R., \& Miller, P. W. (2003). The complementarity of language and other human capital: Immigrant earnings in Canada. Economics of Education Review, 22, 469-480.

Chiswick, B. R., \& Miller, P. W. (2005). Linguistic distance: A quantitative measure of the distance between English and other languages. Journal of Multilingual and Multicultural Development, 26, $1-11$.

Dustmann, C., \& Fabbri, F. (2003). Language proficiency and labour market performance of immigrants in the UK. Economic Journal, 113, 695-717.

Dustmann, C., \& van Soest, A. (2001). Language fluency and earnings: Estimation with misclassified language indicators. Review of Economics and Statistics, 83, 663-674.

Dustmann, C., \& van Soest, A. (2002). Language and the earnings of immigrants. Industrial and Labor Relations Review, 55, 473-492.

Duvander, A.-Z. (2001). Do country-specific skills lead to improved labor market positions? An analysis of unemployment and labor market returns to education among immigrants in Sweden. Work and Occupations, 28, 210-233.

Ekberg, J., \& Rooth, D.-O. (2004). Yrke och utbildning på 2000-talets arbetsmarknad-skillnader mellan inrikes och utrikes födda personer. Integrationsverkets Rapportserie, No. 506, Integrationsverket, Norrköping.

Finnäs, F. (1986). Den finlandssvenska befolkningsutvecklingen 1950-1980. En analys av en språkgrupps demografiska utveckling och effekten av blandäktenskap. Doctoral Dissertation, Åbo Akademi University, Finland.

Finnäs, F. (2003). Migration and return-migration among Swedish-speaking Finns. In R. Höglund, M. Jäntti, \& G. Rosenqvist (Eds.), Statistics, econometrics and society: Essays in honour of Leif Nordberg (pp. 41-54). Research Reports, No. 238. Statistics Finland, Helsinki.

Guiso, L., Sapienza, P., \& Zingales, L. (2006). Does culture affect economic outcomes? Journal of Economic Perspectives, 20, 23-48.

Hedberg, C., \& Kepsu, K. (2003). Migration as a cultural expression? The case of the Finland-Swedish minority's migration to Sweden. Geografiska Annaler, 85B, 67-84.

Leiniö, T.-L. (1984). Inte lika men jämlika? Om finländska invandrares levnadsförhållanden enligt levnadsnivåundersökningarna 1968, 1974 och 1981. Rapport, No. 6, SOFI, Stockholm University.

OECD (2000). Literacy in the information age. Paris: OECD.

Rooth, D.-O. (2004). The effect of language proficiency on employment for immigrants-the case of Sweden. Acta Wexioensia, 55, 81-96.

Rooth, D.-O., \& Åslund, O. (2006). Utbildning och kunskaper i svenska - framgångsfaktorer för invandrade? Stockholm: SNS Förlag.

Rooth, D.-O., \& Saarela, J. (2007). Selection in migration and return migration: Evidence from micro data. Economics Letters, 94, 90-95.

Rosholm, M., Scott, K., \& Husted, L. (2006). The times they are a-changin': Declining immigrant employment opportunities in Scandinavia. International Migration Review, 40, 318-348.

Saarela, J., \& Finnäs, F. (2003a). Social background and education of Swedish and Finnish speakers in Finland. European Journal of Education, 38, 445-456. 
Saarela, J., \& Finnäs, F. (2003b). Unemployment and native language: The Finnish case. Journal of SocioEconomics, 32, 59-80.

Saarela, J., \& Finnäs, F. (2004). Interethnic wage variation in the Helsinki area. Finnish Economic Papers, 17, 35-48.

Saarela, J., \& Finnäs, F. (2006a). Can the low unemployment rate of Swedish speakers in Finland be attributed to structural factors? Journal of Socio-Economics, 35, 498-513.

Saarela, J., \& Finnäs, F. (2006b). Adjustment failures in an immigrant population: Finns in Sweden. Social Indicators Research, 82, 545-563.

Saarela, J., \& Rooth, D.-O. (2006). Fifty years of free labour mobility: How integrated are Finns in the Swedish labour market? International Migration, 44, 119-152.

Skolverket (2000). The foundation for lifelong learning. Rapport, No. 188. Stockholm: Liber.

Dan-Olof Rooth completed his doctorate in economics at Lund University in Sweden in 1999 with his dissertation on Refugee Immigrants in Sweden. He is now a member of the Department of Economics at Kalmar University, Sweden. Currently Dan-Olof is also a research director of SNS, a privately owned research company. Dan-Olof has published in journals such as Journal of Population Economics, International Migration, Economic Letters, and Economic Journal. His current research interests include issues in economic psychology, ethnic discrimination and migration as well as more general research on labor market opportunities of immigrants.

Jan Saarela is an associate professor of economics at Åbo Akademi University, Turku, Finland. Currently he works as a senior lecturer of social policy at the same university's facilities in Vaasa, where he mainly teaches about economic aspects of welfare systems and the use of quantitative methods in the social sciences. He earned his doctoral and licentiate degrees in economics from the Department of Economics and Statistics, Åbo Akademi University, Turku, and his master's degree form the Department of Social Sciences, Åbo Akademi University, Vaasa.

Professor Saarela's empirical work has focused on the study of the Swedish-speaking national minority in Finland, with emphasis on their market outcomes, living conditions, and health patterns, as compared with people of the Finnish-speaking majority. He has also devoted much energy to questions about effects of transfer systems on individuals' labour market behaviour. Currently he is involved in projects the use longitudinal population register data to investigate migration, return migration, and economic integration of migrants.

Professor Saarela has written and with Swedish, Spanish, and Finnish colleagues co-written a number of articles in peer-reviewed journals such as International Migration, Population Studies, Economics Letters, Journal of Population Economics, Social Indicators Research, International Journal of Social Welfare, Journal of Socio-Economics, Demographic Research, Socio-Economic Planning Sciences, European Journal of Education and Applied Economics. 